\title{
Diagnosis and management of chronic cough: similarities and differences between children and adults [version 1; peer
}

review: 2 approved]

\author{
Miles Weinberger (iD, Manju Hurvitz (iD) \\ Rady Children's Hospital, University of California San Diego, San Diego, CA, USA
}

V1 First published: 22 Jul 2020, 9(Faculty Rev):757

https://doi.org/10.12688/f1000research.25468.1

Latest published: 22 Jul 2020, 9(Faculty Rev):757

https://doi.org/10.12688/f1000research.25468.1

\section{Abstract}

Cough is a natural process that protects the airway. Cough can occur spontaneously or voluntarily. It is considered chronic when it is present for longer than 4 weeks in children or 8 weeks in adults. In both, chronic cough causes patient distress and increased healthcare utilization. Etiologies of pediatric chronic cough include asthma, protracted bacterial bronchitis, tracheomalacia, habit cough, and various systemic disorders. While some diagnoses are identifiable by careful history alone, others require testing guided by specific pointers. Flexible fiberoptic bronchoscopy has been an important tool to identify etiologies of chronic cough that were not otherwise apparent. In adults, asthma and bronchitis are well-defined etiologies of chronic cough, but much chronic cough in adults is largely a conundrum.

Reviews of adult chronic cough report that at least $40 \%$ of adults with chronic cough have no medical explanation. Gastroesophageal reflux and upper airway cough syndrome (a.k.a. post-nasal drip) have been common diagnoses of chronic cough, but those diagnoses have no support from controlled clinical trials and have been subjected to multiple published critiques. Cough hypersensitivity is considered to be an explanation for chronic cough in adults who have no other confirmed diagnosis. Gabapentin, a neuromodulator, has been associated with a modest effect in adults, as has speech pathology. While habit cough has not generally been a diagnosis in adults, there is evidence for a behavioral component in adults with chronic cough. Treatment for a specific diagnosis provides a better outcome than trials of cough suppression in the absence of a specific diagnosis. More data are needed for chronic cough in adults to examine the hypothesized cough hypersensitivity and behavioral management. This article reviews etiologies and the treatment of chronic cough in children and the conundrum of diagnosing and treating chronic cough in adults.

\author{
Open Peer Review \\ Approval Status \\ 1 \\ 2 \\ version 1 \\ 22 Jul 2020 \\ Faculty Reviews are review articles written by the \\ prestigious Members of Faculty Opinions. The \\ articles are commissioned and peer reviewed \\ before publication to ensure that the final, \\ published version is comprehensive and \\ accessible. The reviewers who approved the final \\ version are listed with their names and \\ affiliations.
1. Woo-Jung Song, University of Ulsan College of Medicine, Seoul, South Korea \\ 2. Rafał Krenke, Medical University of Warsaw, \\ Warsaw, Poland \\ Any comments on the article can be found at the \\ end of the article.
}


Keywords

Chronic cough, habit cough, tracheomalacia, bronchoscopy

Corresponding author: Miles Weinberger (Miles-weinberger@uiowa.edu)

Author roles: Weinberger M: Conceptualization, Supervision, Writing - Original Draft Preparation; Hurvitz M: Writing - Review \& Editing

Competing interests: No competing interests were disclosed.

Grant information: The author(s) declared that no grants were involved in supporting this work.

Copyright: $\odot 2020$ Weinberger M and Hurvitz M. This is an open access article distributed under the terms of the Creative Commons Attribution License, which permits unrestricted use, distribution, and reproduction in any medium, provided the original work is properly cited.

How to cite this article: Weinberger $M$ and Hurvitz $M$. Diagnosis and management of chronic cough: similarities and differences between children and adults [version 1; peer review: 2 approved] F1000Research 2020, 9(Faculty Rev):757 https://doi.org/10.12688/f1000research.25468.1

First published: 22 Jul 2020, 9(Faculty Rev):757 https://doi.org/10.12688/f1000research.25468.1 


\section{Introduction}

Cough is a natural process that can protect the airway. Stimulation of the pharyngeal area will induce cough to prevent a foreign substance from entering the airway. Irritation of cough receptors in the airways can be stimulated by infection, presence of mucus, or foreign material. Cough is characterized as being "wet" based on the presence of mucus heard or produced. Retention of mucus or the sound of mucus in the airway causes the wet cough, while a non-productive cough is considered dry. The sound of cough comes from the sudden release of air compressed by a previously closed glottis. The sequence is inspiration, glottic closure so that pressure is built, followed by the rapid release of the air. The sound of the cough can vary considerably in pitch, timbre, or loudness. Cough can have a loud barking quality or be so soft that it is essentially a throat-clearing sound. When cough continues daily for more than 4 weeks in children, it is considered to be chronic ${ }^{1}$. The convention in the literature for adults is 8 weeks to define a cough as chronic ${ }^{2}$.

\section{Diagnosing the cause of chronic cough in children}

A prudent approach to identifying the cause of a chronic cough is beginning with the simplest and least-invasive diagnostic measure (Table 1). Progression to more complex and invasive measures should be considered if the diagnosis is not apparent from clinical observation and a careful history. It may be tempting to first consider the most common cause of chronic cough in children or the causes of chronic cough with which the clinician is most familiar. While that may seem logical, an incorrect assumption of the etiology and treatment decision results in the frustration of uninformative testing and failed therapeutic trials. A preliminary physical examination and spirometry for those able to perform the procedure can identify auscultatory and physiological abnormalities that may be related to the chronic cough and provide some direction for further evaluation. However, the etiology of chronic cough in children can generally be identified most accurately and efficiently by beginning with observation, a careful history, and progressing to appropriate tests and therapeutic trials based on pointers obtained in the history, radiology, bronchoscopy, and bronchoalveolar lavage when the diagnosis has not been made from those initial measures ${ }^{3}$.

A diagnosis that can be made by history and observation alone is the habit cough ${ }^{4}$. This disorder has been repeatedly described in children since $1966^{5}$, sometimes with different terminology, including tic ${ }^{6}$, tic-cough ${ }^{7}$, psychogenic $\operatorname{cough}^{8,9}$, and somatic cough disorder ${ }^{10}$. It is seen at major pediatric centers about 7-9 times per year ${ }^{7,11}$. Regardless of the term used, the same description occurs in repeated publications of a characteristic sound of the cough, frequently barking or honking, and the absence of the cough once asleep ${ }^{5,8,9,11-14}$. This is most common

Table 1. A logical approach to the diagnosis of chronic cough for children. The simplest and least-invasive diagnostic tool is history, which can make the diagnosis of habit cough $(A)$ and provides historical pointers to consider diagnoses that require specific testing or therapeutic trial (B-F).

\section{A. Observation and history: frequency of cough—repetitive cough absent once asleep indicates likelihood of habit cough syndrome}

B. Cough present for $<3$ months, especially if spasmodic and disturbs sleep, requires consideration of pertussis syndrome

C. Cough in infant with feeding warrants textured swallow study

D. Cough present since neonatal period, history of transient tachypnea of newborn, and chronic otitis media warrants consideration of primary ciliary dyskinesia

E. Cessation of cough after a short course of an oral corticosteroid is consistent with asthma; further evaluation can determine an appropriate treatment plan. Failure to stop cough with the oral corticosteroid warrants further evaluation

F. A 2-week therapeutic trial of amoxicillin-clavulanate can be considered as an alternative to bronchoscopy and lavage if the historical pointer suggests a "wet" cough in an infant or toddler in making a clinical diagnosis of protracted bacterial bronchitis

1. Radiology, chest X-ray or computerized axial tomography

a. Lobar hyperinflation suggests retained foreign body—consider rigid bronchoscopy

b. Suggestion of airway inflammation or bronchiectasis warrants sweat chloride testing for cystic fibrosis

c. Situs inversus totalis suggests a likelihood of primary ciliary dyskinesia

d. Normal chest X-ray warrants further evaluation

2. Flexible fiberoptic bronchoscopy with bronchoalveolar lavage can determine the following:
a. Airway malacia, trachea or bronchi
b. Protracted bacterial bronchitis 
in children aged 8 to 13 years (mean and median, 10 years) ${ }^{11}$ but has been seen as young as 3 and as old as 16. There is a male predominance, with $58 \%$ of males among 140 diagnoses of habit cough over a 20 -year time span at the University of Iowa and $69 \%$ of 55 children over a 6-year period at the Brompton Hospital in London ${ }^{7,11}$. Classically described as a barking cough, different sounds have been heard in these patients, including a soft cough consistent with throat clearing in about $10 \%{ }^{11}$. Frequent repetitive coughing is characteristic and can occur multiple times per minute, even with every exhalation in some. Others may have spasms of multiple coughs every few minutes. The repetitive cough may be present for hours on end and even during all waking hours. While interference in getting to sleep from this cough is common, a sine qua non for the diagnosis of the habit cough is the absence of cough once asleep ${ }^{14}$.

Another diagnosis that is important to consider by history and observation is pertussis (whooping cough) ${ }^{15}$. The cough is characterized by frequent spasms of coughing followed by nausea or vomiting. The cough can persist for up to 3 months. The frequency and sound of the coughs may be like the barking cough often present with habit cough, but the usual presence of troublesome nocturnal coughing distinguishes this chronic cough from habit cough.

Other aspects of history can point to diagnoses that require specific testing. Chronic wet or productive cough can include asthma $^{16}$, protracted bacterial bronchitis ${ }^{17}$, cystic fibrosis ${ }^{18}$, primary ciliary dyskinesia ${ }^{19}$, or bronchiectasis ${ }^{20}$. Symptoms of asthma and cystic fibrosis can be apparent at any age. Protracted bacterial bronchitis is most common in the infant and toddler ${ }^{21}$. Cough in primary ciliary dyskinesia typically begins in infancy and persists ${ }^{19}$. Bronchiectasis most commonly occurs from the damage caused by the other chronic lung diseases but also occurs in the absence of another lung disease ${ }^{20}$. The etiologies of chronic cough in children referred to a specialty center have been identified using a standardized management pathway ${ }^{21}$.

Cough in asthma is commonly associated with recurrent wheezing and dyspnea, but asthma can be manifested in some cases only with cough and is then called cough-variant asthma or cough-dominant asthma ${ }^{22}$. Asthma is readily identified in both children and adults by a diagnostic therapeutic trial of a short course of prednisone or other systemic corticosteroid ${ }^{22,23}$. Pavard and Chung specifically stated "guidelines recommend a carefully controlled 2-week trial of oral prednisone"24. Similarly, Morice et al. indicated that a therapeutic trial of prednisolone should be offered if diagnoses of cough-predominant asthma or eosinophilic bronchitis are being considered ${ }^{25}$. Cessation of cough from the corticosteroid supports the diagnosis of asthma, while failure to stop the chronic cough eliminates the diagnosis and justifies further evaluation. An alternative recommendation from the Global Initiative for Asthma (GINA) was for a diagnostic trial of a short-acting bronchodilator (SABA) and low-dose inhaled corticosteroid for 2-3 months ${ }^{26}$. Others have recommended just an inhaled corticosteroid for a shorter period to assess if cough is from asthma or using a bronchoprovocation test to examine for the presence of airway reactivity. The GINA recommendation is more expensive, is more problematic for young children, and provides less assurance of successful medication delivery, which is essential for making a diagnostic decision. Examining for airway reactivity is also not an efficient or reliable means of asthma diagnosis ${ }^{27}$.

Cystic fibrosis has a wet cough. Most common in people of Northern European descent, cystic fibrosis occurs in about 1 in 3,000 of the U.S. Caucasian population. Cystic fibrosis is generally diagnosed in childhood and primarily at the newborn stage because of universal newborn screening, but diagnosis is sometimes delayed until adulthood ${ }^{28}$. Diagnosis is by measurement of sweat chloride concentration and genetic identification of deleterious mutations of the gene controlling the cystic fibrosis transmembrane regulator (CFTR), a protein that affects functioning in the sweat glands, respiratory system, digestive system, and reproductive system ${ }^{29}$.

Primary ciliary dyskinesia can be suspected from a chronic wet cough at any age that begins in infancy and persists ${ }^{19}$. Its prevalence in the U.S. is estimated to be at least 1 in 10,000 , much less common than the prevalence of cystic fibrosis. A history of transient neonatal distress is common, thought to be a result of decreased clearance of amniotic fluid from the lungs because of the absence of normal ciliary function. The absence of ciliary action in utero causes random assignment of the organs ${ }^{30}$. Consequently, about $50 \%$ of those with primary ciliary dyskinesia have situs inversus totalis. The disorder has been known as Kartagener's syndrome ${ }^{31}$.

A screening test for primary ciliary dyskinesis is measuring nitric oxide from the nose ${ }^{32}$. Primary ciliary dyskinesis is characterized by extremely low values of nasal nitric oxide. A normal to high value of nasal nitric oxide excludes the diagnosis. Confirmation of the diagnosis can be made by demonstration of defects in the dynein arms of the cilia when seen by electron microscopy or identification of defects in genes that control components of the cilia ${ }^{33}$. But, currently, both identify only about $70 \%$ of cases. Examining ciliary movement by high-speed video-microscopy analysis is used to aid the diagnosis of primary ciliary dyskinesia. This technique enables the identification of absent or dysfunctional ciliary movement.

Radiology can point to various diagnoses. Suggestion of bronchiectasis on plain films can be confirmed with chest computerized tomography (CT). Bronchiectasis occurs with several chronic lung diseases, such as cystic fibrosis and primary ciliary dyskinesia, and early signs of bronchiectasis have been reported in some patients with protracted bacterial bronchitis ${ }^{34}$. Bronchiectasis unrelated to chronic lung disease is also seen ${ }^{20}$.

Flexible bronchoscopy and bronchoalveolar lavage are essential to confirm a diagnosis of protracted bacterial bronchitis, a clinical disorder predominant in infants and toddlers. This disorder has been the most common cause of chronic cough referred to specialty centers. Neutrophilia and greater than 10,000 bacteria/mL in bronchoalveolar fluid are the diagnostic finding $\mathrm{s}^{17}$. The organisms involved are Hemophilus influenzae, Moraxella catarrhalis, 
and Streptococcus pneumoniae, the same organisms involved in otitis media. Clinical response to a 2 -week course of amoxicillinclavulanate is also used as a presumptive diagnostic criterion when the clinical presentation is consistent with protracted bacterial bronchitis. Diagnosis of PBB made by the contents of a bronchoalveolar lavage are then identified as PBB-micro, whereas a diagnosis made based on a clinical response to antibiotics is identified as PBB-clinical ${ }^{35}$. Flexible bronchoscopy, when done properly, entering through the nose with controlled sedation ${ }^{36}$, can identify tracheobronchomalacia ${ }^{37}$ and some uncommon causes of chronic cough ${ }^{38,39}$.

Tracheomalacia or tracheobronchomalacia is a disorder that can occasionally cause chronic cough ${ }^{40}$. It involves tracheal or main stem bronchus collapse to a variable degree. It can be diagnosed only by bronchoscopy performed with light sedation so that dynamic movements can be visualized. Most tracheomalacia or tracheobronchomalacia cause minimal problems. When the collapse of the trachea results in the anterior and posterior walls of the trachea coming into contact, this can result in a nidus of irritation that causes chronic cough ${ }^{41}$.

Other causes of chronic cough in children include foreign body aspiration $^{42}$, which may cause localizing auscultatory findings. An uncommon cause of chronic cough in children is of otogenic etiology ${ }^{43}$, when a foreign body in the ear stimulates Arnold's nerve. Various chronic lung diseases can also be associated with chronic cough but will usually manifest other findings such as tachypnea and hypoxemia that lead to specific investigations.

\section{Treatment of chronic cough in children}

Treatment is dependent on the correct diagnosis. Children with habit cough are often inappropriately treated because the diagnosis is not recognized and treatment is given for other causes of cough with which the physician is more familiar ${ }^{4}$. However, the diagnosis should not be one of exclusion by eliminating other causes of chronic cough first. The clinical presentation of habit cough, a repetitive cough absent once asleep, is sufficiently characteristic to make the diagnosis without further testing or therapeutic trials ${ }^{7,11}$. Recognizing the diagnosis then permits treatment using some form of suggestion therapy, which is generally curative ${ }^{12-14}$. Cough from asthma is readily relieved by a short course of an oral corticosteroid ${ }^{22}$. Cessation of cough by an oral corticosteroid justifies further evaluation to characterize the asthma and consider maintenance medication, such as an inhaled corticosteroid.

Pertussis warrants treatment with a macrolide antibiotic, preferably azithromycin. This eliminates the serious contagiousness of this disorder. However, the clinical course is little affected beyond early treatment ${ }^{44}$. Cystic fibrosis is a multi-system disease. Treatment requires pancreatic enzyme replacement therapy for most ${ }^{45}$. Antibiotics, mucolytic agents, antibiotics, and airway clearance therapy are used to minimize the progressive airway damage that occurs from chronic infection ${ }^{18}$. New medications identified as potentiators and correctors can restore CFTR function $^{46}$.
Treatment of bronchiectasis focuses on the primary disease such as cystic fibrosis or primary ciliary dyskinesia. Mild cylindrical bronchiectasis may be reversible with treatment ${ }^{20}$. It can persist as a disease-causing chronic purulent cough even if the defect causing the disease is pharmacologically restored and progression of the disease is limited. This is now occurring with cystic fibrosis where the bronchiectasis, if previously present, remains even after the CFTR function is restored ${ }^{46}$ Treatment of bronchiectasis, whether from a primary disease or idiopathic, involves airway clearance therapy and antibiotics.

Treatment of primary ciliary dyskinesia has some similarities to that of cystic fibrosis, but the mucus is not as thick and sticky as in cystic fibrosis and responds better to drainage by airway clearance therapy ${ }^{19}$. Antibiotics become more important as the disease progresses with the development of bronchiectasis, though at a slower rate than cystic fibrosis.

Protracted bacterial bronchitis generally responds well to 2 weeks of amoxicillin-clavulanate ${ }^{17}$. Sometimes a longer or repeat course is needed, and frequent recurrences occur requiring repeated treatment. Tonsillectomy eliminates cough from tonsils impinging on the epiglottis ${ }^{39}$. A rare cause of a uvula in contact with the epiglottis causing cough was cured by uvulectomy ${ }^{38}$. The cough of tracheomalacia has a barking quality, much as frequently occurs in habit cough, but persists during sleep, unlike habit $\operatorname{cough}^{37}$. When the cough from tracheomalacia is sufficiently severe and intractable, a procedure known as aortopexy is considered ${ }^{47}$.

Thus, using a systematic approach, the etiology of chronic cough in children is generally diagnosable. Treatment is dictated by the diagnosis. Chronic cough without explanation is rare in children. For the few not initially diagnosable, new etiologies continue to be found ${ }^{48}$.

\section{Diagnosing the cause of chronic cough in adults}

In contrast to the identification of chronic cough in children, chronic cough in adults often remains a conundrum. Asthma is an occasional isolated cause of chronic cough in the absence of other symptoms of asthma for both children and adults ${ }^{49}$. Since asthma, including cough-variant asthma, is a common cause of chronic cough, a course of oral prednisone can be given as a therapeutic trial for both adults and children ${ }^{22-25}$. The response provides diagnostic information. Failure to respond indicates the absence of asthma. Response supports the diagnosis of asthma and warrants consideration for further evaluation and treatment for asthma. Spirometry can provide evidence to support the diagnosis of asthma by demonstrating bronchodilator responsive airway obstruction. Other etiologies commonly attributed to chronic cough in adults, gastroesophageal reflux and upper airway cough syndrome (also known as post-nasal drip), are not seen as a cause of chronic cough in children submitted to a standardized assessment ${ }^{21}$. While gastroesophageal reflux and post-nasal drip (or drainage) are extremely common disorders in otherwise healthy adults ${ }^{50}$, most with these common disorders are not troubled by chronic cough. The incredulousness of these 
diagnoses as a cause of chronic cough has been repeatedly expressed for children ${ }^{51,52}$ and adults ${ }^{53-56}$. Vocal cord dysfunction (VCD) is described as causing chronic cough ${ }^{2}$, but cough was not seen in 49 sequential adolescents with $\mathrm{VCD}^{57}$.

In addition to asthma, angiotensin-converting enzyme inhibitorinduced cough, non-asthma eosinophilic bronchitis, chronic bronchitis, chronic obstructive pulmonary disease, bronchiectasis, pulmonary fibrosis, lung cancer, and obstructive sleep apnea syndrome have been reported to be associated with chronic cough in adults ${ }^{58}$. A review by the European Respiratory Society suggested that, while a wide range of diseases may be associated with chronic cough in adults, the heightened sensitivity of neuronal pathways provides a common pathway that mediates cough $^{59}$. Reviews of chronic cough in adults have reported that $40 \%$ of chronic cough in adults seen at cough centers is without medical explanation ${ }^{2,60}$. Since chronic cough without medical explanation may be termed idiopathic or refractory, cough hypersensitivity as a unifying hypothesis has been an attractive area of investigation ${ }^{61}$.

An additional specific cause of chronic cough reported for adults is enlarged tonsils ${ }^{62,63}$, an observation also made for children $^{39}$. Tracheomalacia, a cause of chronic cough in some children, can also cause chronic cough in adults. However, the etiologies, surgical options, and outcomes are quite different than in children ${ }^{64}$. Aspiration of a foreign object, more common in children, has also been a reported cause of chronic cough in adults $^{65}$. In a Chinese study of adult patients with foreign body aspiration, chronic cough was the most common symptom ${ }^{66}$. A foreign body in the ear stimulating Arnold's nerve causing chronic cough has been described in both children ${ }^{43}$ and adults ${ }^{67}$. Cough can be present in adults with tuberculosis but is usually not present in primary tuberculosis in children. Chronic cough in adults is common in patients with lung infections due to Mycobacterium avium complex, other nontuberculous mycobacteria, fungal diseases, and paragonimiasis ${ }^{68}$.

\section{Treatment of chronic cough in adults}

The recommended etiologies to be treated in reviews are gastroesophageal reflex and upper airway cough syndrome ${ }^{2}$. However, there are only anecdotal guidelines and opinions with no controlled clinical trials to support successful treatment of those postulated disorders ${ }^{52-54}$. When considering lung diseases such as non-asthmatic eosinophilic bronchitis, chronic bronchitis, chronic obstructive pulmonary disease, bronchiectasis, pulmonary fibrosis, lung cancer, and obstructive sleep apnea syndrome, the use of pointers from history, spirometry, radiology, bronchoscopy, and biopsies may be needed. Tonsillectomy, effective in children where the tonsils impinge upon the epiglottis ${ }^{39}$, is reported to be an effective treatment for chronic cough in some adults with enlarged tonsils $^{62,63}$. Similar to the pediatric report ${ }^{38}$, an adult with chronic cough was successfully treated by uvulectomy ${ }^{69}$.

Pharmacologic treatments that modulate neuronal function have been considered for chronic intractable cough in adults when there is no medical diagnosis. Based on the hyperexcitability of neuronal pathways mediating cough, modulating neuronal function has been attempted with morphine, amitriptyline, and gabapentin ${ }^{70}$. The problem of morphine for a chronic cough is self-evident. Amitriptyline apparently has a transient effect on cough suppression, with fewer patients continuing to benefit with time. In a controlled clinical trial, gabapentin decreased mean cough frequency by about $50 \%$ from an initial $45 /$ hour $^{71}$. The rationale for gabapentin as a treatment for chronic cough is based on the postulation that airway nerve endings in the upper airway create the feeling that causes repeated coughing.

Gefapixant is a medication under investigation with the rationale of greater neuromodulator effect ${ }^{72}$. Its mechanism is related to being a P2X3 receptor antagonist. P2X3 receptors are found on peripheral sensory nerves of the airways. At a dose of gefapixant that significantly reduced cough at about the same magnitude as gabapentin, adverse effects, primarily dysgeusia and ageusia, occurred in over half of the 63 patients in the study. While the concept of a neuromodulator approach to treatment is intriguing, it has not been determined if the neurogenic stimulus for the feeling that causes repeated coughing is primary or from the continuing stimulation of the cough itself, a classic chicken and egg question.

A non-pharmacologic approach to suppressing chronic cough has included speech and physical therapy. Examined in a controlled clinical trial, a decrease in mean cough frequency from 17 to 9 per hour was described (a magnitude of benefit similar to that seen with gabapentin or gefapixant $)^{73}$. Dr Mandel Sher, director of a cough center in Florida, noted similarities of habit cough in children and cough identified as neurogenic in adults. Both appear to be triggered by the urge to cough from feeling a sensation in their throat. Both usually occur after a pathologic event, usually a viral respiratory infection. Dr Sher further suggested that the $30-40 \%$ placebo response in various trials further indicates a behavioral component in adult chronic cough ${ }^{74}$. Some adults with chronic cough have reported that their chronic cough stopped from watching a video (https://www.youtube.com/ watch? $v=j n Q U v D 8 Q d j 0)$ of a 12-year-old girl with a 3-month history of chronic cough who stopped coughing while receiving suggestion therapy ${ }^{75}$. Comments received in emails from two adult women, aged 58 and 68, who were among those who stopped coughing after watching the video stated, "I listened to the video and concentrated. It really works." The other stated, "It's amazing mind over matter."

The observation that adults can stop coughing when watching a video of suggestion therapy given to a child suggests a habit cough diagnosis for those adults. However, the presence or absence of the cough when sleeping was not obtained in most of those patients, and absence once asleep is a diagnostic criterion for habit cough. Without further clinical information to support habit cough, the response could be considered a placebo effect ${ }^{76}$. Interestingly, a publication in a book from 1694 described an "habitual cough which often continues after the first cough, which was caused by the cold, is gone, from which....the habitual cough often proceed"77. This 336-year-old description is similar to habit cough in children and intractable chronic cough in adults. Perpetuating after a viral respiratory infection, as apparently described in 1694, chronic cough may be some form of learned 
or neurogenic stimulation or damage initiated by the initial pathology.

\section{Discussion}

In comparing chronic cough in children and adults, there are striking differences but also similarities. The most apparent difference is the diagnosis of children with chronic cough by a systematic approach leaves few without a medical explanation ${ }^{21}$. In contrast, the absence of a medical diagnosis other than the postulate of cough hypersensitivity is common for adults with chronic cough. Consequently, treating a specific diagnosis can occur for children with chronic cough. Without a specific diagnosis other than cough hypersensitivity, treatment of adult chronic cough has focused on pharmacological medication. However, the consensus of expert opinion is that currently available drugs are largely ineffective in the treatment of cough hypersensitivity ${ }^{61}$. On the other hand, limited evidence suggests that behavioral therapy can provide effective treatment options for adult chronic cough without medical explanation, as has been established for children ${ }^{11}$. That evidence includes the observations of Dr Mandel Sher ${ }^{74}$ and the response of some adults to watching a video of a 12-year-old girl being successfully treated with suggestion therapy ${ }^{75}$. Thus, there is limited value of pharmacotherapy for chronic cough in adults and the similarities to habit cough in children suggest further exploration and use of non-medication behavioral responses for chronic unexplained cough in adults.

Further consideration must also be given to the confounding that might occur when a physical cause of sustained cough, asthma in children or adults, chronic bronchitis in adults, and all other lung diseases that can cause cough, may be accompanied by the repetitive nature of the habit cough overlying the organic cough. Most organic causes of chronic cough do not cause the frequent repetitive cough of habit cough. Treating the underlying disorder as usual and the addition of a behavior method may be needed in such cases.

As a final thought for the reader of this review, consideration should be given to the case described by Smith and Woodcock in the New England Journal of Medicine a few years ago ${ }^{60}$. A 63-year-old woman previously in good health had a 1-year history of a chronic dry cough associated with a sensation of "irritation" in the throat. A history and physical exam were uninformative. She was prescribed a bronchodilator, inhaled and nasal glucocorticoids, all without benefit. She had normal spirometry and chest X-ray. The authors of this case then reviewed causes of chronic cough. Among consideration of diagnostic procedures were a 2-month trial of a proton-pump inhibitor, a methacholine challenge, measurement of the fraction of exhaled nitric oxide, high-resolution CT of the thorax, bronchoscopy, and nasendoscopy. If all were negative, treatment options described included slow-release low-dose morphine sulfate, gabapentin, or speech and language therapy. Meanwhile, the authors of this case provided verbal reassurance to the patient that chronic refractory cough may resolve or decrease spontaneously. In other words, they would kick the can down the street after performing tests and trials involving large sums of money. This case study and recommendations from a prestigious journal warrant careful consideration by readers of this review, not because the clinical course and proposed testing and treatment are atypical and unusual but because they aren't. It fits an all-too-common pattern of the experiences of children and adults with chronic cough. The authors of this case expressed no knowledge of a disorder with potential relevance to their patient that was described over 300 years $\operatorname{ago}^{77}$ and in children since then ${ }^{5,11,13,14}$. Utilizing updated information since that ancient report of "habitual cough", we challenge the reader of this review to think about how they would have managed this lady based on current knowledge.

\section{Summary}

There are multiple causes of chronic cough. A systematic approach involves first a careful history. Habit cough, though less common than other causes, generally can be diagnosed by the history alone. The history in children also provides pointers that lead to specific diagnostic tests for asthma, cystic fibrosis, primary ciliary dyskinesia, protracted bacterial bronchitis, and tracheomalacia. Flexible fiberoptic bronchoscopy can identify etiologies for chronic cough that were not otherwise apparent. Treatment of a specific diagnosis provides better outcome than therapeutic trials of cough suppressants. More and better data are needed for chronic cough in adults in order to select the best therapy. The suggestion of a response to behavioral approaches in adults warrants further investigation.

\section{Acknowledgements}

We thank Mr. Dennis Buettner of the Internet Broadcast Network for www.habitcough.com and his success in obtaining and providing a 1694 publication describing habitual $\operatorname{cough}^{77}$. We express our appreciation for the thoughtful comments Dr Mandel Sher of the Center for Cough in Largo Florida placed online in a member communication program of the American College of Allergy and Immunology.
1. Chang $A B$, Oppenheimer JJ, Weinberger MM, et al.: Use of Management Pathways or Algorithms in Children With Chronic Cough: CHEST Guideline and Expert Panel Report. Chest. 2017; 151(4): 875-83. PubMed Abstract | Publisher Full Text

2. Gibson PG: Management of Cough. J Allergy Clin Immunol Pract. 2019; 7(6):
1724-9.

PubMed Abstract | Publisher Full Text

3. Weinberger M, Fischer A: Differential diagnosis of chronic cough in children. Allergy Asthma Proc. 2014; 35(2): 95-103. PubMed Abstract | Publisher Full Text 
4. Weinberger $M$, Lockshin $B$ : When is cough functional, and how should it be treated? Breathe (Sheff). 2017; 13(1): 22-30.

PubMed Abstract | Publisher Full Text | Free Full Text

5. Berman BA: Habit cough in adolescent children. Ann Allergy. 1966; 24(1): 43-6. PubMed Abstract

6. Pringsheim T: POINT: Is the Term Habit Cough an Inaccurate Use of a Term? Yes. Chest. 2019; 156(6): 820-1.

PubMed Abstract | Publisher Full Text

7. Wright MFA, Balfour-Lynn IM: Habit-tic cough: Presentation and outcome with simple reassurance. Pediatr Pulmonol. 2018; 53(4): 512-6. PubMed Abstract | Publisher Full Text | Faculty Opinions Recommendation

8. Kravitz H, Gomberg RM, Burnstine RC, et al:: Psychogenic Cough Tic in Children and Adolescents. Nine Case Histories Illustrate the Need for Re-Evaluation of This Common but Frequently Unrecognized Problem. Clin Pediatr (Phila). 2016; 8(10): 580-3.

PubMed Abstract | Publisher Full Tex

9. Weinberg EG: 'Honking': Psychogenic cough tic in children. S Afr Med J. 1980; 57(6): 198-200.

Publed Abstract

10. Vertigan AE, Murad MH, Pringsheim T, et al.: Somatic Cough Syndrome (Previously Referred to as Psychogenic Cough) and Tic Cough (Previously Referred to as Habit Cough) in Adults and Children: CHEST Guideline and Expert Panel Report. Chest. 2015; 148(1): 24-31. PubMed Abstract | Publisher Full Text | Free Full Text

11. Weinberger $M$, Hoegger $M$ : The cough without a cause: Habit cough syndrome. J Allergy Clin Immunol. 2016; 137(3): 930-1.

PubMed Abstract | Publisher Full Text

12. Cohlan SQ, Stone SM: The cough and the bedsheet. Pediatrics. 1984; 74(1) $11-5$

PubMed Abstract

13. Lokshin $\mathrm{B}$, Lindgren $\mathrm{S}$, Weinberger $\mathrm{M}$, et al:: Outcome of habit cough in children treated with a brief session of suggestion therapy. Ann Allergy. 1991; 67(6): 579-82.

PubMed Abstract

14. Weinberger M: The habit cough: Diagnosis and treatment. Pediatr Pulmonol. 2018; 53(5): 535-7.

PubMed Abstract | Publisher Full Text

15. Harnden A, Grant C, Harrison T, et al.: Whooping cough in school age children with persistent cough: prospective cohort study in primary care. $B M J$. 2006; 333(7560): 174-7.

PubMed Abstract | Publisher Full Text | Free Full Text |

Faculty Opinions Recommendation

16. Weinberger M: Pediatric asthma and related allergic and nonallergic diseases: Patient-oriented evidence-based essentials that matter. Pediatric Health. 2008; 2: $631-50$

Publisher Full Text

17. Kompare $\mathrm{M}$, Weinberger $\mathrm{M}$ : Protracted bacterial bronchitis in young children Association with airway malacia. $J$ Pediatr. 2012; 160: 88-92.

PubMed Abstract | Publisher Full Text

18. O'Sullivan BP, Freedman SD: Cystic fibrosis. Lancet. 2009; 373: 1891-904. PubMed Abstract | Publisher Full Text

19. Bush A, Chodhari R, Collins N, et al.: Primary ciliary dyskinesia: Current state of the art. Arch Dis Child. 2007; 92(12): 1136-40. PubMed Abstract | Publisher Full Text | Free Full Text

20. Chang $A B$, Bush A, Grimwood K: Bronchiectasis in children: Diagnosis and treatment. Lancet. 2018; 392(10150): 866-79. PubMed Abstract | Publisher Full Text | Faculty Opinions Recommendation

21. Chang AB, Robertson CF, van Asperen PP, et al:: A multicenter study on chronic cough in children: Burden and etiologies based on a standardized management pathway. Chest. 2012; 142(4): 943-50.

PubMed Abstract | Publisher Full Text | Faculty Opinions Recommendation

22. Doan T, Patterson R, Greenberger PA: Cough variant asthma: Usefulness of diagnostic-therapeutic trial with prednisone. Ann Allergy. 1992; 69(6): 505-9. PubMed Abstract

23. Weinberger M, Abu-Hasan M: Asthma in the pre-school child. Kendig's Disorders of the Respiratory Tract in Children. 8th edition, Edited by V. Chernick, TF Boat, RW Wilmott, A Bush. Saunders Elsevier, Philadelphia, 2012; 686-698.

Publisher Full Text

24. Pavord ID, Chung KF: Management of chronic cough. Lancet. 2008; 371(9621): 1375-84.

PubMed Abstract | Publisher Full Text

25. Morice AH, McGarvey L, Pavord I: Recommendations for the management of cough in adults. Thorax. 2006; 61(Suppl 1): i1-24.

PubMed Abstract | Publisher Full Text | Free Full Text

26. Global Strategy for Asthma Management and Prevention (2020 update) from the Global Initiative for Asthma, Chapter 6, Section 2, Children under 5 years. Accessed 6-22-2020.

Reference Source

27. Weinberger M: Pediatric bronchial hyperresponsiveness and asthma .

PubMed Abstract | Publisher Full Text
28. Nick JA, Nichols DP: Diagnosis of Adult Patients with Cystic Fibrosis. Clin Chest Med. 2016; 37: 47-57.

PubMed Abstract | Publisher Full Text

29. Bienvenu T, Nguyen-Khoa T: Current and future diagnosis of cystic fibrosis: Performance and limitations. Arch Pediatr. 2020; 27(Suppl 1): eS19-eS24. PubMed Abstract | Publisher Full Text | Faculty Opinions Recommendation

30. Roomans GM, Ivanovs A, Shebani EB, et al:: Transmission electron microscopy in the diagnosis of primary ciliary dyskinesia. Ups J Med Sci. 2006; 111(1): $155-68$.

PubMed Abstract | Publisher Full Text

31. Andrews CT: Kartagener's Syndrome. BMJ. 1949; 2: 1269. PubMed Abstract | Publisher Full Text | Free Full Text

32. C Shapiro AJ, Dell SD, Gaston B, et al:: Nasal Nitric Oxide Measurement in Primary Ciliary Dyskinesia. A Technical Paper on Standardized Testing Protocols. Ann Am Thorac Soc. 2020; 17(2): e1-e12.

PubMed Abstract | Publisher Full Text | Free Full Text |

Faculty Opinions Recommendation

33. Leigh MW, Horani A, Kinghorn B, et al:: Primary ciliary dyskinesia (PCD): A genetic disorder of motile cilia. Trans/ Sci Rare Dis. 2019; 4(1-2): 51-75. PubMed Abstract | Publisher Full Text | Free Full Text | Faculty Opinions Recommendation

34. Eg KP, Mirra V, Chang AB, et al.: Editorial: Chronic Suppurative Lung Disease and Bronchiectasis in Children and Adolescents. Front Pediatr. 2017; 5: 196. PubMed Abstract | Publisher Full Text | Free Full Text

35. Kantar A, Chang AB, Shields MD, et al.: ERS statement on protracted bacterial bronchitis in children. Eur Respir J. 2017; 50(2): 1602139.

PubMed Abstract | Publisher Full Text

36. Wood RE: Pitfalls in the use of the flexible bronchoscope in pediatric patients. Chest. 1990; 97(1): 199-203.

PubMed Abstract | Publisher Full Text

37. Wood RE: Localized tracheomalacia or bronchomalacia in children with intractable cough. J Pediatr. 1990; 116(3): 404-6. PubMed Abstract | Publisher Full Text

38. Najada A, Weinberger M: Unusual cause of chronic cough in a four-year-old cured by uvulectomy. Pediatr Pulmonol. 2002; 34(2): 144-6. PubMed Abstract | Publisher Full Text

39. Gurgel RK, Brookes JT, Weinberger MM, et al.: Chronic cough and tonsilla hypertrophy: A case series. Pediatr Pulmonol. 2008; 43(11): 1147-1149. PubMed Abstract | Publisher Full Text

40. Wallis C, Alexopoulou E, Antón-Pacheco JL, et al.: ERS statement on tracheomalacia and bronchomalacia in children. Eur Respir J. 2019; 54(3) 1900382

PubMed Abstract | Publisher Full Text | Faculty Opinions Recommendation

41. Ghezzi M, Silvestri M, Sacco O, et al.: Mild tracheal compression by aberrant innominate artery and chronic dry cough in children. Pediatr Pulmonol. 2016; 51(3): 286-94.

PubMed Abstract | Publisher Full Text

42. Molloy S, Batchelor G, McCadden L, et al.: Cough and you'll miss it. Arch Dis Child Educ Pract Ed. 2019.

PubMed Abstract | Publisher Full Text | Faculty Opinions Recommendation

43. Smith FM Jr: Arnold's nerve reflex; a little known cause of cough in pediatric patients. J La State Med Soc. 1963; 115: 17-8. PubMed Abstract

44. Cherry JD: Treatment of Pertussis-2017. J Pediatric Infect Dis Soc. 2018; 7(3): 123-e125.

PubMed Abstract | Publisher Full Text | Faculty Opinions Recommendation

45. Nassif EG, Younoszai MK, Weinberger MM, et al:: Comparative effects of antacids, enteric coating, and bile salts on the efficacy of oral pancreatic enzyme therapy in cystic fibrosis. J Pediatr. 1981; 98(2): 320-3. PubMed Abstract | Publisher Full Text

46. CKeating D, Marigowda G, Burr L, et al.: VX-445-Tezacaftor-Ivacaftor in Patients with Cystic Fibrosis and One or Two Phe508del Alleles. N Engl J Med. 2018; 379(17): 1612-1620.

PubMed Abstract | Publisher Full Text | Free Full Text

Faculty Opinions Recommendation

47. Rijnberg FM, Butler CR, Bieli C, et al:: Aortopexy for the treatment of tracheobronchomalacia in 100 children: A 10-year single-centre experience. Eur J Cardiothorac Surg. 2018; 54(3): 585-592.

PubMed Abstract | Publisher Full Text | Faculty Opinions Recommendation

48. C Spencer CY, Millman J, Veiga K, et al:: Airway Autoimmune Inflammatory Response (AAIR) Syndrome: An Asthma-Autoimmune Overlap Disorder? Pediatrics. 2018; 141(3): e20170138.

PubMed Abstract | Publisher Full Text | Faculty Opinions Recommendation

49. Corrao WM, Braman SS, Irwin RS: Chronic Cough as the Sole Presenting Manifestation of Bronchial Asthma. N Engl J Med. 1979; 300(12): 633-7. PubMed Abstract | Publisher Full Text

50. Irwin RS, French CL, Chang AB, et al:: Classification of Cough as a Symptom in Adults and Management Algorithms: CHEST Guideline and Expert Panel Report. Chest. 2018; 153(1): 196-209.

PubMed Abstract | Publisher Full Text | Free Full Text 
51. de Benedictis FM, Bush A: Respiratory manifestations of gastro-oesophageal reflux in children. Arch Dis Child. 2018; 103(3): 292-6.

PubMed Abstract | Publisher Full Text

52. Kemp A: Does post-nasal drip cause cough in childhood? Paediatr Respir Rev. 2006; 7(1): 31-5.

PubMed Abstract | Publisher Full Text

53. Morice AH: Post-nasal drip syndrome-a symptom to be sniffed at? Pulm Pharmacol Ther. 2004; 17(6): 343-5.

PubMed Abstract | Publisher Full Text

54. Madanick RD: Extraesophageal presentations of GERD: Where is the science? Gastroenterol Clin North Am. 2014; 43(1): 105-20. PubMed Abstract | Publisher Full Text

55. O'Hara J, Jones NS: "Post-nasal drip syndrome": Most patients with purulent nasal secretions do not complain of chronic cough. Rhinology. 2006; 44(4): 270-3.

PubMed Abstract

56. Rimmer J, Lund VJ: Simulated postnasal mucus fails to reproduce the symptoms of postnasal drip in rhinitics but only in healthy subjects. Rhinology. 2015; 53(2): 195-203.

PubMed Abstract | Publisher Full Text

57. Doshi DR, Weinberger MM: Long-term outcome of vocal cord dysfunction. Ann Allergy Asthma Immunol. 2006; 96: 794-9. PubMed Abstract | Publisher Full Text

58. Mathur A, Liu-Shiu-Cheong PSK, Munro A, et al: Chronic cough: A practica approach to assessment and management. Drug Ther Bull. 2019; 57(5): 74-9. PubMed Abstract | Publisher Full Text | Faculty Opinions Recommendation

59. Morice $\mathrm{AH}$, Millqvist $\mathrm{E}$, Bieksiene $\mathrm{K}$, et al.: ERS guidelines on the diagnosis and treatment of chronic cough in adults and children. Eur Res J.2020 55(1): 1901136.

PubMed Abstract | Publisher Full Text | Free Full Text |

Faculty Opinions Recommendation

60. Smith JA, Woodcock A: Chronic Cough. N Engl J Med. 2016; 375: 1544-51. Publisher Full Text

61. Morice AH, Millqvist E, Belvisi MG, et al.: Expert opinion on the cough hypersensitivity syndrome in respiratory medicine. Eur Res J. 2014; 44(5): 1132-48.

PubMed Abstract | Publisher Full Text

62. Birring SS, Passant C, Patel RB, et al.: Chronic tonsillar enlargement and cough: Preliminary evidence of a novel and treatable cause of chronic cough. Eur Res J. 2004; 23(2): 199-201.

PubMed Abstract | Publisher Full Text

63. Lehrer JF: Hypertrophic lingual tonsils and cough. West J Med. 1986; 144(2): (2)

PubMed Abstract | Free Full Text

64. Carden KA, Boiselle PM, Waltz DA, et al: Tracheomalacia and

Tracheobronchomalacia in Children and Adults: An In-Depth Review. Chest.
2005; 127(3): 984-1005.

PubMed Abstract | Publisher Full Text

65. Willett LL, Barney J, Saylors G, et al:: An Unusual Cause of Chronic Cough.

Foreign Body Aspiration. J Gen Intern Med. 2006; 21(12): C1-C3.

PubMed Abstract | Publisher Full Text | Free Full Text

66. Chen $\mathrm{CH}$, Lai CL, Tsai TT, et al.: Foreign body aspiration into the lower airway in Chinese adults. Chest. 1997; 112(1): 129-33.

PubMed Abstract | Publisher Full Text

67. Gold KR, Wester JL, Gold R: Foreign Body in External Ear Canal: An Unusual Cause of Chronic Cough. Am J Med. 2017; 130(4): e143-e144.

PubMed Abstract | Publisher Full Text

68. Field SK, Escalante P, Fisher DA, et al:: Cough Due to TB and Other Chronic Infections: CHEST Guideline and Expert Panel Report. Chest. 2018; 153(2): 467-97.

PubMed Abstract | Publisher Full Text | Free Full Text | Faculty Opinions Recommendation

69. Miller FR, Tucker HM: An Elongated Uvula Producing Chronic Cough. Otolaryngol Head Neck Surg. 1993; 109(5): 954-5. PubMed Abstract | Publisher Full Text

70. Giliberto JP, Cohen SM, Misono S: Are neuromodulating medications effective for the treatment of chronic neurogenic cough? Laryngoscope. 2017; 127(5): $1007-8$

PubMed Abstract | Publisher Full Text | Free Full Text

71. Ryan NM, Birring SS, Gibson PG: Gabapentin for refractory chronic cough: A randomised, double-blind, placebo-controlled trial. Lancet. 2012; 380(9853): 1583-9.

PubMed Abstract | Publisher Full Text | Faculty Opinions Recommendation

72. N Smith JA, Kitt MM, Morice AH, et al.: Gefapixant, a P2X3 receptor antagonist, for the treatment of refractory or unexplained chronic cough: A randomised, double-blind, controlled, parallel-group, phase $2 \mathrm{~b}$ trial. Lancet Respir Med.

double-bi.

PubMed Abstract | Publisher Full Text | Faculty Opinions Recommendation

73. Chamberlain Mitchell SAF, Garrod R, Clark L, et al: Physiotherapy, and speech and language therapy intervention for patients with refractory chronic cough: A multicentre randomised control trial. Thorax. 2017; 72(2): 129-36. A multicentre randomised control trial.

74. On-line response of Dr: Mandel Sher related to a discussion of similarities between neurogenic cough in adults and habit cough in children. Reference Source

75. Weinberger M: Unexpected and unintended cure of habit cough by proxy. Ann Allergy Asthma Immunol. 2019; 123(5): 515-6.

PubMed Abstract | Publisher Full Text

76. Kaptchuk TJ, Miller FG: Placebo Effects in Medicine. N Engl J Med. 2015; 373(1): $8-9$

PubMed Abstract | Publisher Full Text

77. Mercuruis F: Habitual cough, in The Spirit of Diseases. Published in 1694. Printed for Sarah Hawkins in George-Tard, in Lambard-street. 


\section{Open Peer Review}

\section{Current Peer Review Status:}

\section{Editorial Note on the Review Process}

Faculty Reviews are review articles written by the prestigious Members of Faculty Opinions. The articles are commissioned and peer reviewed before publication to ensure that the final, published version is comprehensive and accessible. The reviewers who approved the final version are listed with their names and affiliations.

\section{The reviewers who approved this article are:}

\section{Version 1}

\section{Rafał Krenke}

Department of Internal Medicine, Pulmonary Diseases and Allergy, Medical University of Warsaw, Warsaw, Poland

Competing Interests: No competing interests were disclosed.

\section{Woo-Jung Song}

Department of Allergy and Clinical Immunology, Airway Sensation and Cough Research Laboratory, Asan Medical Center, University of Ulsan College of Medicine, Seoul, South Korea

Competing Interests: No competing interests were disclosed.

The benefits of publishing with F1000Research:

- Your article is published within days, with no editorial bias

- You can publish traditional articles, null/negative results, case reports, data notes and more

- The peer review process is transparent and collaborative

- Your article is indexed in PubMed after passing peer review

- Dedicated customer support at every stage

For pre-submission enquiries, contact research@f1000.com

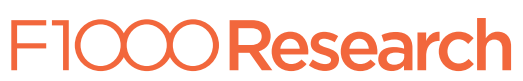

